\title{
PENGARUH MODEL PEMBELAJARAN KOOPERATIF TIPE STUDENT TEAMS ACHIEVEMENT DIVISION (STAD) TERHADAP HASIL BELAJAR PASSING SEPAKBOLA
}

\author{
I Gede Surya Tama', I Wayan Artanayasa', I Made Satyawan ${ }^{3}$ \\ 1,2,3 Prodi Pendidikan Jasmani, Kesehatan dan Rekreasi \\ Universitas Pendidikan Ganesha \\ Singaraja, Indonesia

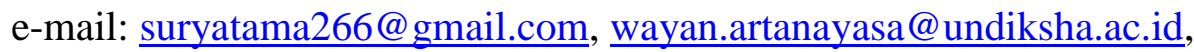 \\ anduksatya@yahoo.com
}

\begin{abstract}
Abstrak
Penelitian ini bertujuan untuk mengetahui pengaruh model pembelajaran STAD terhadap hasil belajar teknik dasar passing (kaki bagian dalam dan kaki bagian luar) sepakbola. Jenis penelitian adalah eksperimen sungguhan (true experimental) dengan rancangan the randomized pretest-posttest control group the same subjec design. Populasi penelitian ini adalah seluruh siswa kelas VIII SMP Negeri 7 Singaraja tahun pelajaran 2018/2019, keseluruhan kelas berjumlah 5 kelas dengan populasi 158 orang. Pengambilan sampel yang digunakan simple random sampling berdasarkan kelas. Kelas yang menjadi sampel penelitian adalah kelas VIIIA sebagai kelompok eksperimen dan VIIIB sebagai kelompok kontrol. Eksperimen dilakukan sebanyak 2 kali perlakuan diluar pretes-posttest. Data hasil belajar dikumpulkan melalui tes objektif, observasi dan unjuk kerja. Analisis data menggunakan uji-t dengan bantuan SPSS 16.0 for Windows. Rata-rata kelompok eksperimen adalah 0.61 lebih tinggi dari rata-rata kelompok kontrol adalah 0.50. Signifikansi pada uji hipotesis diperoleh melalui uji parametrik (uji Independent Samples Test) adalah 0.001 yaitu $\mathrm{p}<0,05$. Disimpulkan bahwa model pembelajaran STAD berpengaruh signifikan terhadap hasil belajar teknik dasar passing (kaki bagian dalam dan kaki bagian luar) sepakbola. Disarankan kepada guru penjasorkes dapat menerapkan model pembelajaran STAD karena terbukti berpengaruh signifikan terhadap hasil belajar siswa.
\end{abstract}

Kata-kata kunci : model pembelajaran STAD, hasil belajar teknik dasar passing sepakbola

\begin{abstract}
This research aimed to determine the effect of STAD learning model to the learning outcomes of basic techniques passing (inner leg and outer leg)football. This research was a true-experimental researching the randomized pretest-posttest control group the same subject design. The research population was students of class VIIJunior High School academic year 2018/2019, with the 5 classes and population of the research was 158 peoples. Sampling technique used was simple random sampling based on class. The class into the sample was class VIIIA as experimental group and VIIIB as control group.The experimental was conducted two times treatment outside of pretestposttest.Data were collected through objectif tests, observation and performance tests.Data analysis using t-test with SPSS 16.0 for Windows. Average on experimental group was 0.61 higher than average control was 0.50 . Significance on tests of
\end{abstract}


hypotheses obtained through parametric test (independent Samples Test) was 0.001 it was $\mathrm{p}<0,05$. Based on the above exposure, STAD learning model effect significantly to the result of learning basic techniques passing football.It is recommended to the penjasorkes teacher can implement STAD learning model because proven effect significantly to the improvement of student's learning outcome.

Keywords : STAD learning model, learning outcome techniques passing football.

\section{PENDAHULUAN}

Pembelajaran adalah suatu proses interaksi yang terjadi dua arus atau hubungan timbal balik antara guru, siswa dan antara sesama siswa dalam satuan pembelajaran dengan mendambakan hasil belajar yang optimal. Salah satu komponen dalam proses pembelajaran merupakan pemegang peran yang sangat penting adalah guru, bukan hanya sekadar penyampai materi saja, tetapi guru juga dapat dikatakan sebagai sentral pembelajaran. Guru diharapkan dapat menyiapkan model pembelajaran dengan baik dan tepat sehingga peserta didik lebih mudah membangun pemahamannya sendiri, karena berpengaruh pada hasil belajar siswa. Siswa diharapkan dapat berperan penuh dalam proses pembelajaran dengan guru sebagai fasilitator. Model pembelajaran yang dimaksud adalah model pembelajaran yang dapat melibatkan banyak siswa dalam proses pembelajaran sehingga membantu siswa lebih aktif dan kreatif dalam beraktivitas. Proses pembelajaran merupakan inti dari kegiatan pendidikan di sekolah khususnya dalam pembelajaran pendidikan jasmani olahraga dan kesehatan (PJOK). Pendidikan jasmani juga bertujuan ikut membantu meningkatkan kualitas manusia Indonesia seutuhnya yang menekankan pada pembinaan perilaku hidup sehat, dengan menganut prinsip pendidikan melalui jasmani. Pembelajaran PJOK merupakan media untuk mendorong perkembangan keterampilan motorik, kemampuan fisik, pengetahuan, penalaran, penghayatan nilai (sikap, mental, emosional, spiritual, sosial), dan pembiasaan pola hidup sehat yang bermuara untuk merangsang pertumbuhan serta perkembangan yang seimbang.

Berdasarkan data satu tahun terakhir yang peneliti peroleh dari guru PJOK kelas VIII SMP N 7 Singaraja mengenai proses pembelajaran PJOK materi passing sepakbola berupa hasil belajar, bahwa nilai hasil ulangan harian materi bola besar (sepakbola) teknik dasar passing pada siswa kelas VIII masih banyak ditemukan siswa yang belum memenuhi Kriteria Ketuntasan Minimal (KKM). Dari data hasil belajar pengamatan awal di kelas VIII yang berjumblah 5 kelas dengan jumblah 158 siswa, yang dikategorikan tidak tuntas sebanyak 108 siswa (72\%) dan yang tuntas 50 siswa $(33,3 \%)$. KKM yang harus dicapai siswa kelas VIII adalah 68. Frekuensi nilai tersebut harus ditingkatkan kearah perolehan nilai yang lebih tinggi, yaitu $\geq 68$. Sebaran nilai ini menunjukan adanya proses pembelajaran yang masih belum optimal. Kondisi ini juga diakibatkan karena kurangnya kerjasama antara guru dengan siswa dan sesama siswa satu dan yang lainnya, hal inilah yang menyebabkan pembelajaran kurang optimal.

Disamping itu, model pembelajaran yang digunakan bersifat 
monoton serta kurang memperhatikan kemampuan individu siswa, padahal kemampuan setiap individu siswa belum tentu sama, yaitu latar belakang yang berbeda-beda, latar belakang sosial, tingkat prestasi dan kemampuan setiap individu. Sehingga memerlukan inovasi pembelajaran yang sesuai, agar hasil pembelajaran PJOK dapat berjalan sesuai dengan tujuan. Untuk itu diberikan inovasi pembelajaran yang sesuai dengan latar belakang tersebut maka dari permasalahan diatas dapat diambil solusi dengan menerapkan model pembelajaran kooperatif tipe STAD.

$\begin{array}{lcr}\text { Menurut } & \text { Slavin } & (2005: 4) \text {, } \\ \text { "Cooperative } & \text { Learning } & \text { atau } \\ \text { pembelajaran kooperatif sebagai } & \text { salah } \\ \text { satu model pembelajaran yang }\end{array}$ menyenangkan dan siswa akan lebih paham". Pembelajaran kooperatif memungkinkan siswa belajar dengan berkelompok untuk saling berdiskusi dan bersaing. Pembelajaran kooperatif menjadikan siswa lebih aktif dalam belajar. Ada banyak jenis dari pembelajaran kooperatif dan salah satunya adalah Student Teams Achievement Division (STAD). "Model pembelajaran kooperatif tipe STAD merupakan salah satu model pembelajaran kooperatif yang paling sederhana, dan model yang paling baik bagi para guru yang baru menggunakan pendekatan kooperatif" (Slavin, 2005:4). Model pembelajaran kooperatif tipe STAD dipilih karena model pembelajaran ini menekankan keterlibatan siswa secara penuh dalam kelompok, dan siswa sebagai subyek belajar yang mana berperan aktif di setiap proses pembelajaran, selain itu bisa melatih siswa dalam berkomunikasi, menyampaikan pendapat, dan dapat mengetahui tingkat kemajuan hasil belajar siswa. Dalam pembelajaran kooperatif tipe STAD merupakan salah satu tipe dari model pembelajaran kooperatif dengan menggunakan kelompok-kelompok kecil dengan jumlah anggota tiap kelompok 4-5 orang yang merupakan campuran menurut tingkat prestasi, jenis kelamin, dan suku. Diawali dengan penyampaian tujuan pembelajaran, penyampaian materi, kegiatan kelompok, kuis, dan penghargaan kelompok.

Berdasarkan pemilihan model pembelajaran kooperatif tipe STAD yang dikemukakan oleh peneliti Suarta tahun (2017) menemukan bahwa "hasil belajar teknik dasar pada materi pokok passing sepakbola berpengaruh signifikan melalui implementasi model pembelajaran kooperatif tipe STAD terhadap hasil belajar siswa pada materi pokok passing di kelas X SMA Negeri 1 Sawan"

Berdasarkan uraian di atas peneliti tertarik untuk mengadakan penelitian dengan judul "Pengaruh penerapan model pembelajaran kooperatif tipe Student Teams Achievement Division (STAD) terhadap hasil belajar passing sepakbola

\section{METODE PENELITIAN}

Penelitian ini dilakukan di SMP Negeri 7 Singaraja, Kecamatan Buleleng, Kabupaten Buleleng pada tahun pelajaran 2018/2019. Penelitian ini berlangsung selama lima bulan yang dibagi atas beberapa kegiatan: (1) penyusunan proposal penelitian, yaitu bulan Januari sampai dengan Februari 2019, (2) pelaksanaan penelitian dilakukan pada tanggal 9 Maret sampai dengan 20 April 2019, dan (3) penyusunan laporan penelitian selama satu bulan yaitu bulan Mei.

Rancangan pada penelitian ini adalah rancangan the randomize pretest-posttest control group. 
Populasi dalam penelitian ini adalah siswa kelas VIII SMP Negeri 7 Singaraja yang tersebar kedalam 5 kelas yaitu VIII A, VIII B, VIII C, VIII D, dan VIII E. Teknik pengambilan sampel menggunakan cluster random sampling yaitu kelima kelas tersebut diundi untuk menetapkan kelas yang menjadi kelas eksperimen dan kelas kontrol. Berdasarkan hasil pengundian diperoleh sampel penelitian yaitu kelas VIII A sebagai kelompok eksperimen yang berjumlah 32 orang dan VIII B sebagai kelompok kontrol yang berjumlah 32 orang, sehingga keseluruhan jumlah subjek penelitian adalah 64 orang.

\section{HASIL DAN PEMBAHASAN}

Data tentang hasil belajar teknik dasar passing sepakbola (kaki bagian dalam dan kaki bagian luar) diperoleh melalui tes untuk kelompok eksperimen dan kelompok kontrol. Data hasil belajar teknik dasar passing sepak bola diperoleh melalui selisih antara hasil pre-test dan post-tes atau data GSn (Gain Score yang ternormalisasi), dengan rumus:

$$
\mathrm{GSn}=\frac{\text { Gain Score }}{(\text { skor maksimal }- \text { pretest })}
$$

(Dantes, 2017:71)

Tabel 1. Rangkuman Hasil Analisis Data Hasil Belajar Teknik Dasar Passing Sepak Bola

\begin{tabular}{l|c|c|c}
\hline \multicolumn{1}{c|}{ Variabel } & Banyak Siswa & Rata- rata & Std. Deviation \\
\hline Kelas kelompok eksperimen & 32 & 0.61 & 0.127 \\
Kelas kelompok kontrol & 32 & 0.50 & 0.131 \\
\hline
\end{tabular}

Berdasarkan tabel 1 tentang hasil data dikedua kelompok sampel diperoleh rata-rata skor GSn kelompok eksperimen $=0.61$ sedangkan rata-rata skor kelompok kontrol $=0.50$ Standar deviasi dari kelompok eksperimen $=$
0.127 sedangkan standar deviasi dari kelompok kontrol $=0.131$.

Sebelum dilanjutkan ke uji perbedaan rerata maka dilakukan uji prasyarat terlebih dahulu untuk menentukan apakah data berdistribusi normal dan varians homogen.

Tabel 2. Hasil Uji Normalitas Sebaran Data

\begin{tabular}{lcccccc}
\hline & \multicolumn{3}{c}{ Kolmogorov-Smirnov $^{\mathrm{a}}$} & \multicolumn{3}{c}{ Shapiro-Wilk } \\
& Statistic & Df & Sig. & Statistic & Df & Sig. \\
\hline Eksperimen & .145 & 32 & .085 & .916 & 32 & .016 \\
Kontrol & .147 & 32 & .078 & .912 & 32 & .012 \\
\hline
\end{tabular}

Uji homogenitas varians dilakukan dengan pengelompokan berdasarkan model pembelajaran, yaitu model pembelajaran kooperatif tipe Student Team Achievement Division (STAD) dengan model pembelajaran konvensional. Berdasarkan tabel 2 diketahui bahwa untuk kelompok eksperimen sig value $0,085>0,05$ dan kelompok kontrol yaitu sig value 0,078 $>0,05$ yang artinya kedua sampel berasal dari populasi yang berdistribusi normal. 
Uji homogenitas varians antar kelompok dilakukan dengan bantuan SPSS 16.00 for Windows dengan menggunakan Levene's Test Of Equality Error Variance. Hipotesis statistik yang diuji dalam pengujian homogenitas adalah sebagai berikut.

$H_{o} \quad$ : variansi pada setiap kelompok adalah sama (homogen)
$H_{a} \quad$ : variansi pada setiap kelompok tidak sama (tidak homogen)

Dengan kriteria pengujian yang digunakan adalah terima $H_{o}$ jika nilai $p>$ 0,05 dimana data memiliki varians yang sama apabila angka signifikansi yang dihasilkan lebih dari 0,05. Rangkuman hasil perhitungan homogenitas data menggunakan SPSS 16.00 for Windows dapat dilihat pada Tabel 3.

Tabel 3. Rangkuman Hasil Uji Homogenitas Varians menggunakan Levene's Test of Equality of Error Variances ${ }^{a}$

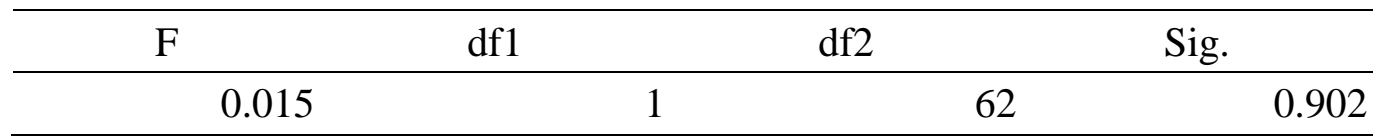

Berdasarkan tabel 3, hasil uji Levene's menunjukkan bahwa untuk hasil belajar teknik dasar passing sepak bola siswa taraf signifikansi $0,902>0,05$. Dapat disimpulkan bahwa variansi pada setiap kelompok adalah sama (homogen).

Hipotesis penelitian yang telah dikemukakan dalam kajian pustaka menyatakan bahwa terdapat perbedaan hasil belajar teknik dasar passing sepak bola pada siswa yang dibelajarkan menggunakan model pembelajaran kooperatif tipe STAD dengan siswa yang dibelajarkan menggunakan model pembelajaran konvensional. Pengujian hipotesis menggunakan uji $\mathrm{t}$ dengan bantuan SPSS 16.00 for Windows. Oleh karena variansi homogen maka dipilih Uji-t dengan bantuan SPSS 16.00for windows. Data yang dianalisis adalah data Gain score ternormalisasi (GSn). Hasil analisis dengan Uji-t disajikan pada Tabel 4 berikut ini.

Tabel 4. Hasil Uji-t dengan Menggunakan SPSS Independent Samples Test

\begin{tabular}{|c|c|c|c|c|c|c|c|c|}
\hline & & \multicolumn{7}{|c|}{ t-test for Equality of Means } \\
\hline & & \multirow[t]{2}{*}{$t$} & \multirow[t]{2}{*}{$D f$} & \multirow[t]{2}{*}{$\begin{array}{l}\text { Sig. (2- } \\
\text { tailed) }\end{array}$} & \multirow[t]{2}{*}{$\begin{array}{c}\text { Mean } \\
\text { Difference }\end{array}$} & \multirow[t]{2}{*}{$\begin{array}{l}\text { Std. Error } \\
\text { Difference }\end{array}$} & \multicolumn{2}{|c|}{$\begin{array}{l}95 \% \text { Confidence } \\
\text { Interval of the } \\
\text { Difference }\end{array}$} \\
\hline & & & & & & & Lower & Upper \\
\hline $\begin{array}{l}\text { Gains } \\
\text { core }\end{array}$ & $\begin{array}{c}\text { Equal } \\
\text { variances } \\
\text { assumed }\end{array}$ & 3.397 & 62 & 0.001 & 0.10938 & 0.03220 & 0.04501 & 0.17374 \\
\hline
\end{tabular}

Berdasarkan tabel 4 diperoleh nilai signifikansinya $=0,001$. Hasil ini dijadikan dasar dalam mengambil keputusan. Adapun keputusan yang diambil adalah tolak $H_{o}$ dan terima $H_{a}$. Hasil ini menyatakan bahwa terdapat perbedaan hasil belajar teknik dasar passing sepakbola antara siswa yang 
dibelajarkan menggunakan model pembelajaran kooperatif tipe STAD dengan siswa yang dibelajarkan menggunakan model pembelajaran konvensional. Oleh karena rata-rata skor pada kelompok eksperimen $(0,61)$ lebih besar daripada rata-rata skor kelompok kontrol $(0,50)$ maka disimpulkan bahwa hasil belajar pada siswa yang dibelajarkan menggunakan model pembelajaran kooperatif tipe STAD lebih signifikan daripada siswa yang dibelajarkan menggunakan model pembelajaran konvensional.

Berdasarkan hasil penelitian diperoleh bahwa terdapat perbedaan hasil belajar teknik dasar passing sepakbola antara siswa yang dibelajarkan dengan model pembelajaran kooperatif tipe STAD dengan siswa yang dibelajarkan dengan model pembelajaran konvensional, ini berarti model pembelajaran kooperatif tipe STAD berpengaruh terhadap hasil belajar teknik dasar passing sepakboa (kaki bagian dalam dan kaki bagian luar) siswa. Dibuktikan pemilihan model pembelajaran kooperatif tipe STAD yang dikemukakan oleh peneliti Suarta tahun (2017) menemukan bahwa "hasil belajar teknik dasar pada materi pokok passing sepakbola berpengaruh signifikan melalui implementasi model pembelajaran kooperatif tipe STAD terhadap hasil belajar siswa pada materi pokok passing di kelas X SMA Negeri 1 Sawan", Sari (2015) "Pengaruh model pembelajaran kooperatif tipe STAD berbantuan media gambar terhadap keterampilan proses sains dan hasil belajar Siswa Kelas XI Mia SMA N 1 Bangun Purba Tahun Pembelajaran 2014/2015" penelitian ini menyimpulkan hasil model pembelajaran kooperatif tipe STAD berbantuan media gambar berpengaruh terhadap keterampilan proses sains dan hasil belajar siswa kelas XI MIA SMA
N 1 Bangun Purba Tahun Pembelajaran 2014/2015.

\section{SIMPULAN DAN SARAN Simpulan}

Berdasarkan hasil analisis data dan pembahasan dapat disimpulkan bahwa penerapan model pembelajaran kooperatif tipe STAD $\quad(\mathrm{p}<0,05)$ berperngaruh signifikan terhadap peningkatan hasil belajar teknik dasar passing (menggunakan kaki bagian dalam dan kaki bagian luar) sepak bola pada siswa kelas VIII SMP Negeri 7 Singaraja tahun pelajaran 2018/2019.

\section{Saran}

Berdasarkan simpulan hasil analis data yang diperoleh, maka dapat diajukan beberapa saran untuk proses pembelajaran dan penelitian lebih lanjut sebagai berikut.

1. Bagi guru Penjasorkes, model pembelajaran kooperatif tipe STAD dapat dijadikan salah satu alternatif pembelajaran yang dapat diterapkan di kelas.

2. Penelitian ini dilaksanakan pada pokok bahasan teknik dasar passing sepak bola di kelas VIII SMP Negeri 7 Singaraja, sehingga untuk memperoleh bukti-bukti yang lebih umum dari penerapan model pembelajaran kooperatif tipe STAD diharapkan peneliti lain untuk mencoba pada pokok bahasan lain untuk mengetahui pengaruh penerapan model pembelajaran kooperatif tipe STAD dalam pembelajaran Penjasorkes secara lebih mendalam.

3. Penelitian ini hanya mengukur ada atau tidaknya pengaruh dari model pembelajaran kooperatif tipe STAD terhadap hasil belajar teknik dasar passing sepak bola (menggunakan kaki bagian dalam dan kaki bagian luar) tanpa meneliti lebih jauh arah 
pengaruh yang diberikan. Di waktu mendatang dapat dilakukan suatu penelitian untuk meneliti sejauh mana arah pengaruh yang diberikan oleh model pembelajaran kooperatif tipe STAD terhadap hasil belajar Penjasorkes siswa.

\section{DAFTAR PUSTAKA}

Artanayasa, I Wayan. 2016. Pengaruh Model Pembelajaran dan Penilaian Autentik Terhadap Hasil Belajar Keterampilan Sepakbola dengan Mengontrol Motor Educability. Jakarta: Universitas Negeri Jakarta.

Dantes, Nyoman. 2002. Metode Penelitian. Yogyakarta: ANDI

Departemen Pendidikan Nasional, 2007. Pembelajaran PJOK Inovatif untuk Pendidikan Dasar.Surabaya: Departemen Pendidikan Nasional.

Dimyati dan Mudjiono. 2006. Belajar dan Pembelajaran. Jakarta: Rineka Cipta.

Husdarta. 2009. Manajemen Pendidikan Jasmani. Bandung: Alfabeta.

Kanca, I Nyoman. 2010. Metodologi Penelitian Pengajaran Pendidikan Jasmani dan Olahraga. Singaraja : Universitas Pendidikan Ganesha

Luxbacher, A. J. 2012. Sepak Bola. Cetakan Kelima. Jakarta: PT. Raja Grafindo Persada

Sari, Nirmala. 2015. Pengaruh Model Pembelajaran Kooperatif Tipe Student Team Achievement Division (Stad) Berbantuan Media Gambar Terhadap Keterampilan Proses Sains Dan Hasil Belajar Siswa Kelas Xi Mia Sma N 1 Bangun Purba Tahun Pembelajaran 2014/2015.
Tersedia pada: http://ejournal.upp.ac.id/index.php/fkip biologi/article/view/348 (diakses tanggal 27 Februari 2019).

Suarta, I komang dkk. (2017). Pengaruh penerapan model pembelajaran kooperatif tipe Student Teams Achievement Division (Stad) Terhadap Hasil Belajar Teknik Dasar Passing Sepak Bola. "eJournalPJKR "Universitas Pendidikan Ganesha Jurusan Pendidikan Jasmani, Kesehatan, dan Rekreasi (Vol 8, No 2, Tahun 2017). Tersedia pada http://ejournal.undiksha.ac.id (diakses tanggal 5 januari 2019) 